duction. The author has drawn heavily upon the publications of the National Resources Committee and of the various "1313" organizations at Chicago.

One of the features of Professor Harold Zink's recent book on City Government which met with universal acclaim, and which it might be well to note at this point, is a new technique of scholarship which seems to have developed what bids fair to revolutionize in a most progressive manner the business of preparing textbooks and books for public consumption. Public agencies such as the Resources Committee, and semipublic agencies such as the Public Administration Clearing House, are performing the preliminary task of discovering problems and preparing extensive materials on them; the competent scholars are then permitted to devote their talents to the constructive task of presenting such materials to the public in compact form.

Professor Wells begins properly with an analysis of local government, which he defines in such a way as to exclude the state governments. Applying the criteria of function, of area, and of self-government, he arrives at the conclusion that local government units consist of the counties, incorporated places, towns and townships, school districts, and other such districts enumerated by Anderson in his classification. A rapid survey of his first chapter indicates that the problems of local government in Professor Wells's mind are maldistribution of population, of resources, of wealth, and of community facilities, a progressive deterioration in the quantity of the population, and a differential lowering of standards of living which have resulted in remedial action on the part of state and national governments whereby the traditional balance of power between these units has been disturbed.

In his chapters on the Citizen and Local Government, Wells reaffirms the judgment of many observers that civic indifference is growing and that, notwithstanding the extraordinary assistance rendered citizens by means of governmental research, adult education, local forums, and so on, political parties oriented toward national politics but organized on a local basis still hinder the effective and intelligent expression of the public will.

In Chapter Three the author considers the problem of areas and structures, and by his very enumeration of units and relationships indicates the need for a drastic reorganization of these units on a uniform basis. The Federal Government is credited with initiative and wise direction in the attainment of financial stability, adequate welfare, efficient engineering enterprises, improved personnel, and constructive planning. One of the most interesting sections in the book is Wells's page on the co-operative solution to the problem of local government (page 131).

As is the case with all works which are concise, this volume omits consideration of many problems that students of local government care to have discussed; but $I$, for one, welcome the publication of a book that does not repeat the bearded tales of James Bryce, Gilbertson, and Lincoln Steffens.

\section{Indiana University}

Roy V. Peel

OgG, Frederic Austin. European Governments and Politics. 2nd Ed. Pp. viii, 936. New York: The Macmillan Co., 1939. $\$ 4.25$.

The political science profession has long been indebted to Professor Ogg for his thorough and complete textbooks on American and European governments. Written to fill large and important needs in the teaching of basic courses, these widely used books have been revised and kept up to date. The book under review, dealing with the governments of the principal European countries, has had a wide and successful use since its first appearance in 1934, and is now presented to us in a second, thoroughly revised edition.

The task of analyzing and portraying the forms and functions of so many great governmental systems is difficult and arduous. But Professor Ogg, with his years of background and experience in these fields, plus his great ability in collecting and digesting the extensive literature in such a wide field, is able not merely to pull vast quantities of significant data together in logical order, but also to give to his syn- 
thesis penetration, wise observation, and sound conclusions.

It is not difficult to find fault with the author's distribution of space among the various countries. Out of 916 pages of text, twenty chapters, or 398 pages, are devoted to the British section, which is "largely adapted" from the author's English Government and Politics. This is nearly half of the book, while Soviet Russia is dealt with summarily and quite inadequately in only 57 pages. Germany is allotted 195 pages, only about 90 of which deal with the Nazi system. Here the author's decision to give 75 pages to the Weimar system is, in the reviewer's opinion, sound and commendable. But such a choice necessarily restricted his treatment of the present regime.

One could also differ with Professor Ogg about his opinion of proportional representation and its effect in undermining the German democratic system (p. 728); or he could wonder why no attention at all was given to the French colonial empire or to Nazi foreign policy. But considering the work as a whole, one would be captious indeed if he allowed such disagreements to minimize the general excellence and scholarly quality of the whole book. This new edition of a standard work has been carefully edited and well indexed, and in every respect is an up-to-date and highly useful addition to the field.

\section{University of Michigan}

\section{James K. Pollock}

Ziegler, BenJamin Munn. The International Law of John Marshall. Pp. xii, 386. Chapel Hill: University of North Carolina Press, 1939. \$3.50.

"Why another book on John Marshall?" The author answers his own question in the expression of the hope "that it will find a place as a necessary supplement and complement to the many works already published dealing with John Marshall, and that as a study of first principles of the law of nations, it can in a small measure at least act as a beacon of hope and guidance in the development of these newer principles which chart the course of progress."

The book deals with the entire sphere of the conventional international law from Grotius to Marshall's time and with Marshall's influence upon his contemporaries and epigones. It might well be classified as a scholarly study of the evolution of modern international law in theory and application. It expounds or quotes generously from Grotius, Bynkershoek, Pufendorf, Vattel, Blackstone, and others, as sources from which Marshall has drawn. It refers copiously to Story, Kent, Wheaton, Stowell, and others, as collaborators, supporters, or followers of Marshall, as the case may be.

There are times when the reader cannot but wonder whether the author is using the subject matter of international law for the purpose of extolling Marshall's contribution to that field of the law, his patriotism, his intellectual capacity, his honesty. There are other times when one has to struggle against the thought that Marshall becomes a convenient shield for the learned treatment of the law of nations, which seems to go far beyond Marshall's connection with or influence upon the matter.

Neither the Marshall nor the law of nations presented in the book is new or is claimed to be new; what is new is the setting in which Marshall, as we know him from other writings, examines, expounds, applies, and expands the international law of the time as he knew and we know it from many works. But that aspect in itself should suffice to assure for the book a permanent place among the Marshalliana as well as in the basic literature on the history of the attempts to establish what we call international law.

\section{Johns Hopkins University}

$$
\text { Johannes Mattern }
$$

Haddow, Anna. Political Science in American Colleges and Universities, 16361900. Pp. xiv, 308. New York: D. Appleton-Century Co., 1939. \$2.50.

Political science is the foster child of moral philosophy. When Aristotle referred to it as the queen of the sciences he had in mind a broader content than is normally given to the term today. There is indeed a good deal to be said for the view that the divorce of the social sciences from moral 